\title{
BALD EAGLES STEAL FISH FROM RIVER OTTERS
}

\section{PETER TAYLOR, Box 597, Pinawa, Manitoba. RoE 1 Lo}

Bald Eagles are versatile and opportunistic predators, obtaining food by a combination of hunting, fishing, scavenging and piracy. ${ }^{4,5}$ The victims of their piracy are often other fish-eating or scavenging birds, such as Ospreys, mergansers, gulls, crows, and vultures, as well as other Bald Eagles. ${ }^{2,3,4,5}$ Bald Eagles are also known to rob Sea Otters (Enhydra lutris). ${ }^{5,7}$ Two published accounts of interactions with River Otters (Lutra canadensis; hereafter, otters) are discussed below. ${ }^{1,6}$

Within the last ten years, I have received three independent, anecdotal reports of adult Bald Eagles taking fish from otters during winter at different places along the Winnipeg River in southeastern Manitoba. The observers and locations were: Jack Lamb at Pointe du Bois in late winter 1982; Glen and Coleen McGee near Seven Sisters Falls in mid-December 1987; and Bud and Kay Burwell at Otter Falls in December 1991. All the observers work or live within sight of permanent open water, and each reported eagles stealing fish from otters several times.

In every case, the otter was observed with a fish, hauled onto the ice at the edge of open water. By flying close to the otter, the eagle would drive it into the water and then take possession of the abandoned fish. Although observations were not recorded in detail, there was no mention of an eagle ever striking an otter, nor of any significant defensive action other than retreat by the otters.
There are at least two published accounts of related interactions between Bald Eagles and otters. ${ }^{1,6}$ In January 1975 a Bald Eagle, an otter and an unidentified fish were all found dead on the ice bordering a salt-water inlet at Terra Nova National Park, Newtoundland. Wounds on the eagle and otter were consistent with a battle over possession of the fish. ${ }^{6}$ In Wisconsin, Beckel observed two interactions between Bald Eagles and otters during more than 200 hours of otter observation. ${ }^{1}$ In both cases, an eagle "attacked" an otter with a large fish, but the otter retained possession of the fish by carrying it back into the water.

In winter, open water on the Manitoba portion of the Winnipeg River is usually limited to a few short stretches $(<1 \mathrm{~km})$ of fast, turbulent flow and some longer stretches (1-3 $\mathrm{km})$ downstream from the six hydroelectric dams, which include Pointe du Bois and Seven Sisters Falls. Migrating or overwintering Bald Eagles, as well as otters, are frequently observed at these localities, especially in December and March. Limited open water probably increases contact between the two species. Since the stretches of open water are largely surrounded by river ice, the otters are much more conspicuous (and hence, presumably, more vulnerable to piracy) than at other seasons.

Few eagles overwinter in Manitoba, but one or two have done so at Seven Sisters Falls almost 
annually since 1981-1982, and less regular mid-winter records have also occurred at McArthur Falls. The latest fall migrants along the Winnipeg River typically leave in midDecember, and the first spring arrivals are usually observed in midMarch.

Since piracy on otters does not involve pursuit, the energy benefit to the eagles, as discussed by Fischer, would seem to be greater than is the case with piracy on birds. ${ }^{3}$ The reports by Beckel and Rosen, however, indicate that this behaviour is neither 100 percent successful, nor risk free. ${ }^{1,6}$ Severe cold weather and limited fishing and hunting opportunities for Bald Eagles at the northern extremity of their inland winter range are likely a driving force for this piracy. ${ }^{4}$ It is possible that theft from otters is a significant source of food for some Bald Eagles in winter.

I thank Jon Gerrard for helpful comments on this note. I would be interested to learn of any other observations of interactions between Bald Eagles and otters.

1. BECKEL, A.L. 1981. Interactions between Bald Eagles and North American River Otters. Passenger Pigeon 43:3-4.

2. BROCKMAN, H.J. and C.J. BARNARD. 1979. Kleptoparasitism in birds. Anim. Behav. 27:487-514.

3. FISCHER, D.L. 1985. Piracy behaviour of wintering Bald Eagles. Condor 87:246-251.

4. GERRARD, J.M. and G.R. BORTOLOTTI. 1988. The Bald Eagle: haunts and habits of a wilderness monarch. Western Producer Prairie Books, Saskatoon. 178 pp.

5. PALMER, R.S., J.M. GERRARD and M.V. STALMASTER. 1988. Bald Eagles: Haliaeetus leucocephalus (Linneaus). In: Handbook of North American birds. Vol. 4. Diurnal raptors (Part 1). Edited by R. S. Palmer. Yale University Press, New Haven, CT.

6. ROSEN, M. 1975. Bald Eagle and River Otter. Can. Field-Nat. 89:455.

7. SHERROD, S.K., C.M. WHITE and F.S.L. WILLIAMSON. 1976. Biology of the Bald Eagle on Amchitka Island. Living Bird 15:143-182.

A sage, on how he became so wise: The rocks were among my first teachers. From them I have learned how to sit and be still. Once I did this, I began to notice everything around me in a new way. An oak tree taught me the difference one life can make: I saw how this oak tree and its brethren warmed the cold winter and made the summer's heat more pleasant; how the forest animals came to the tree for shelter, food and comfort. Since then I have tried to live for others. Cornell, 1987. Listening to Nature, Dawn Publications. 